\title{
IL4 RECEPTOR (+1902G), IL18 (-607A) AND VEGF (C-2578A) SINGLE-NUCLEOTIDE POLYMORPHISMS WERE NOT ASSOCIATED WITH NECROTIZING ENTEROCOLITIS RISK
}

\author{
R.M. Moonen ${ }^{1}$, G. Cavallaro ${ }^{2}$, I. Reyes ${ }^{3}$, G. González-Luis ${ }^{3}$, F. Mosca ${ }^{2}$, E. Villamor ${ }^{4}$
}

${ }^{1}$ Paediatrics, Atrium Medical Centre Parkstad, Heerlen, The Netherlands, ${ }^{2}$ Institute of Pediatrics and Neonatology, Fondazione IRCCS Ospedale Maggiore Policlinico, Mangiagalli e Regina Elena, University of Milan, Milan, Italy, ${ }^{3}$ Pediatrics, Hospital Universitario Materno-Infantil de Canarias, Las Palmas de Gran Canaria, Spain, ${ }^{4}$ Pediatrics, Maastricht University Medical Center (MUMC+), GROW School, Maastricht, The Netherlands

Background and aims: The pathophysiology of necrotizing enterocolitis (NEC) remains elusive and is likely multifactorial. Inadequate response of the inflammatory cytokine cascade and the intestinal circulatory regulation may play a role in the development of NEC. We have examined associations between variants in candidate interleukin (IL) and vascular endothelial growth factor (VEGF) genes with susceptibility to NEC in preterm infants.

Methods: DNA samples were collected from 28 preterm infants (gestational age $\leq 30 \mathrm{wk}$ and birth weight $<$ $1500 \mathrm{~g}$ ) with established NEC (Bell's stage $\geq \mathrm{II}$ ), 82 controls matched for gestational age and ethnic group and 96 term infants. IL 4 receptor (+1902G), IL18 (-607A) and VEGF (C-2578A) single-nucleotide polymorphisms (SNP) were genotyped and analyzed for their association with NEC.

Results: All allele distributions were in Hardy-Weinberg equilibrium. Variant genotypes of IL4 receptor, IL18 and VEGF in cases, controls, and term infants are listed in the table.

\begin{tabular}{|c|c|c|c|c|c|c|c|c|}
\hline \multicolumn{3}{|c|}{ IL4r (+1902G) } & \multicolumn{3}{|c|}{ IL18 (-607A) } & \multicolumn{3}{|c|}{ VEGF (C-2578A) } \\
\hline \multicolumn{3}{|c|}{$\begin{array}{c}\mathrm{AA} / \mathrm{AG} / \mathrm{GG} \text { (prevalence of } \mathrm{G} \text { allele } \\
(\%))\end{array}$} & \multicolumn{3}{|c|}{$\begin{array}{c}\mathrm{CC} / \mathrm{CG} / \mathrm{GG}(\text { prevalence of } \mathrm{G} \text { allele } \\
(\%))\end{array}$} & \multicolumn{3}{|c|}{$\begin{array}{c}\mathrm{AA} / \mathrm{AC} / \mathrm{CC}(\text { prevalence of A allele } \\
(\%))\end{array}$} \\
\hline $\begin{array}{l}\text { NEC } \\
(n=28)\end{array}$ & $\begin{array}{c}\text { non-NEC } \\
(\mathrm{n}=80)\end{array}$ & $\begin{array}{l}\text { term } \\
(\mathrm{n}=95)\end{array}$ & $\begin{array}{l}\text { NEC } \\
(n=28)\end{array}$ & $\begin{array}{c}\text { non-NEC } \\
(\mathrm{n}=82)\end{array}$ & $\begin{array}{c}\text { term } \\
(\mathrm{n}=93)\end{array}$ & $\begin{array}{l}\text { NEC } \\
(\mathrm{n}=28)\end{array}$ & $\begin{array}{c}\text { non-NEC } \\
(\mathrm{n}=78)\end{array}$ & $\begin{array}{c}\text { term } \\
(\mathrm{n}=96)\end{array}$ \\
\hline $\begin{array}{c}21 / 7 / 0 \\
(13)\end{array}$ & $\begin{array}{l}49 / 26 / 5 \\
(23)\end{array}$ & $\begin{array}{l}56 / 29 / 10 \\
(26)\end{array}$ & $\begin{array}{c}7 / 14 / 7 \\
(50)\end{array}$ & $\begin{array}{l}24 / 34 / 24 \\
(50)\end{array}$ & $\begin{array}{l}18 / 48 / 27 \\
(55)\end{array}$ & $\begin{array}{c}8 / 14 / 6 \\
(54)\end{array}$ & $\begin{array}{c}11 / 47 / 20 \\
(44)\end{array}$ & $\begin{array}{c}16 / 47 / 33 \\
(41)\end{array}$ \\
\hline
\end{tabular}

None of the studied SNPs was significantly associated with NEC.

Conclusions: In contrast to earlier reports, None of the candidate SNPs so far studied was significantly associated with NEC risk in preterm infants. Data from earlier, the present, and future association studies of these SNPs may be added to a meta-analyses to obtain more precise estimates of effects sizes. 